\title{
The Long Road to Shared PCK: a Science Teacher's Personal Journey
}

\author{
Bartolomé Vázquez-Bernal ${ }^{1}$ (D) - Vicente Mellado ${ }^{2}$ [D $\cdot$ Roque Jiménez-Pérez $^{1}$ (D)
}

Accepted: 16 September 2021 / Published online: 26 October 2021

(c) The Author(s) 2021, corrected publication 2022

\begin{abstract}
Teachers' development can be seen as a dialog between their reflective thinking and their actions, with an added gradient of complexity from their social interactions. All of these elements are conjugated within their classroom practice, with their Pedagogical Content Knowledge (PCK) as theoretical background. This paper analyzes the case of a secondary education science teacher's development over different periods, with a focus on classroom atmosphere, social organization and problem-based interactions, the influence of the topic being taught, and the teacher's participation in an Action-Research group. The sources of information included the teacher's diaries, questionnaires, interviews, ethnographic records, and extracts from videotaped sessions of her lessons. The data analysis for the areas of reflection and of action was approached with methodological plurality. Although these two fields of study (reflection and action) share essential aspects, they presented subtle differences, with reflection being more fully developed than action in the classroom, and the contribution of the Action-Research group to the teacher's development was important, but less so than her professional command of the content. Two underlying obstacles deeply rooted in the teacher's thinking and actions impregnate her classroom interactions: classroom competitiveness, and the use of excessively rigid activities.
\end{abstract}

Keywords PCK · Case study $\cdot$ Classroom atmosphere $\cdot$ Social organization $\cdot$ Problembased interactions

\section{Introduction}

Classrooms are complex systems in which the teacher plays a key role, teaching, but also learns and acquires knowledge, and this learning is bound to influence in turn how the pupils go about constructing their own knowledge. However, this process is not devoid of obstacles due to its intrinsic complexity, interactivity, and feedback (Morin, 1999). The word "obstacle" is used in this context for something that literally or figuratively stands in

Bartolomé Vázquez-Bernal

bartolome.vazquez@ddcc.uhu.es

1 Integrated Didactics Department, Facultad de Educación, Psicología y Ciencias del Deporte,

University of Huelva, Av. de las Fuerzas Armadas, S/N; 21071, Huelva, Spain

2 Science and Mathematics Didactics Department of the University of Extremadura, Badajoz, Spain 
the way of an individual's development. Bachelard (1983) identifies it as a form of knowledge that has in general been satisfactory for a time to solve certain problems, and thus becomes anchored in the mind, but subsequently, in the face of new problems, it proves to be inadequate and hard to adapt. Astolfi and Peterfaivi (1999) prefer to talk more about the identification of problems than removing obstacles. When seen in this way, an obstacle could be interpreted as an alternative form of a teacher's thinking that influences their reflections and actions.

The theoretical basis used is a construct that has been widely developed in recent decades known as Pedagogical Content Knowledge (PCK). A hypothesis of complexity was used as a methodological tool for the analysis (Vázquez-Bernal et al., 2007). This study reveals the obstacles to a particular teacher's professional development that she had to overcome, and others that remain, as well as the possibilities for further future development in a profession that depends on complex interrelationships (Murray, 2014).

\section{Backgrounds}

\section{PCK: a Theoretical Construct in Development}

The concept of PCK was introduced by Shulman (1986) who described it as a special amalgam of content and the teacher's own pedagogy, i.e., their own particular way of comprehending their profession. At the end of the 1990s, there seemed to be a degree of consensus that science teachers' PCK included knowledge of the pupils' thinking about science, the science curriculum, science-specific instructional strategies, evaluation of pupils' science learning, and approaches to teaching science (Magnusson et al., 1999). In the 20 years since then, there have been periodic and interesting reviews about this concept (Depaepe et al., 2013; Kam Ho \& Hume, 2019), from which we would stress the scarcity of longitudinal studies about teacher development.

Gess-Newsome (2015) emphasizes that PCK is a personal attribute of a teacher as it is based on the teacher's actions and core knowledge. According to that study, there is a teacher's professional knowledge base which consists of curricular, pupil, content, pedagogical, and evaluation knowledge, and this base in turn shapes topic-specific professional knowledge or TSPK (instructional strategies, content representations, pupil understanding and development, science practices, and habits of mind).

Recently, this model has evolved into a more refined form (Carlson \& Daehler, 2019) that describes the complex layers of knowledge and experience that shape and inform teachers' scientific practice throughout their professional careers, and, in turn, measures pupil outcomes: collective PCK (cPCK), personal PCK (pPCK), and enacted PCK (ePCK).

Park and Oliver (2008) found that what the teacher does in the classroom (enactment) is informed by knowledge-on-action, but also involves decision making on the spot and therefore requires a more dynamic kind of knowledge called knowledge-in-action. This relationship between teacher PCK and what the teacher does in the classroom is inherently complex (Barendsen \& Henze, 2019). Taking these considerations into account, we look for patterns within the enacted PCK or specific knowledge and skills used by a teacher in a particular setting to achieve specific pupil outcomes. Over time, these patterns can help capture the pPCK or teacher's personal knowledge and unique expertise about teaching a given subject, the result of the cumulative experiences, and contributions from pupils, peers, and others (Carlson \& Daehler, 2019). However, the search for 
patterns that make up the pPCK implies the existence of development stages that must be formulated; at this point, the complexity hypothesis comes into play, as it is rooted in the teacher's reflection and action (Anderson, 2019).

\section{The Complexity Hypothesis: a Methodological Approach}

Although using different terminologies, some authors have established various levels in teachers' reflection (Taggart \& Wilson, 2005), establishing a desirable final level that depends on the social and emancipatory character of the teacher. The complexity hypothesis (HC) is conceived of as the development of the teacher's competence to interact in an emancipatory way with the social context and sustainable with the natural environment through action-oriented reflection (Vázquez-Bernal et al., 2012). It is structured around three dimensions - technical, practical, and critical-with a hierarchical structure. The technical dimension is associated with what has been called technical rationality, i.e., the effective instrumental application of educational knowledge, an obstacle (Habermas, 1987). The practical dimension accepts a commitment to resolve the practical problems that affect teaching and learning, and whose resolution guides the teacher's reflection. In the complexity hypothesis, this is not a genuine obstacle, but it is considered to be the transition to the desirable dimension (critical), not incompatible with the practical dimension, to which it introduces social, environmental, and ethical criteria into the educational discourse, adding complexity to the practical problems.

Table 1 presents an instrumentalization based on the scientific literature carried out by the authors, in an interactive process that resolves for each analysis structure (classroom atmosphere, social organization, and problem-based interactions) the obstacle to overcome, what is desirable in emancipatory and sustainable terms, and the characteristics of the transition.

We see that there is a gradient of social interaction shared between the Refined Consensus Model (RCM) of PCK and the complexity hypothesis. The interaction between both constructions, being the contribution of this study to science education, allows adding a developmental perspective to the RCM between the desirable knowledge, cPCK, and the obstacles that must be overcome, or at least become aware of them. Therefore, when studying reflection and action, we are talking about a set of categories that can help in investigating the pPCK and obstacles that could be located at different levels (knowledge base, topic-specific professional knowledge, teacher beliefs, context, or classroom practice).

\section{Research Questions}

How do a science teacher's reflection and action develop and integrate over time, at specific moments, and in different teaching/learning contexts and what obstacles must the teacher confront? However, given the breadth of the general research question, we focus it on the obstacles related to the social dimensions of the classroom atmosphere (research question 1), the social organization (research question 2), and problem-based interactions (research question 3 ) the teacher must confront. 


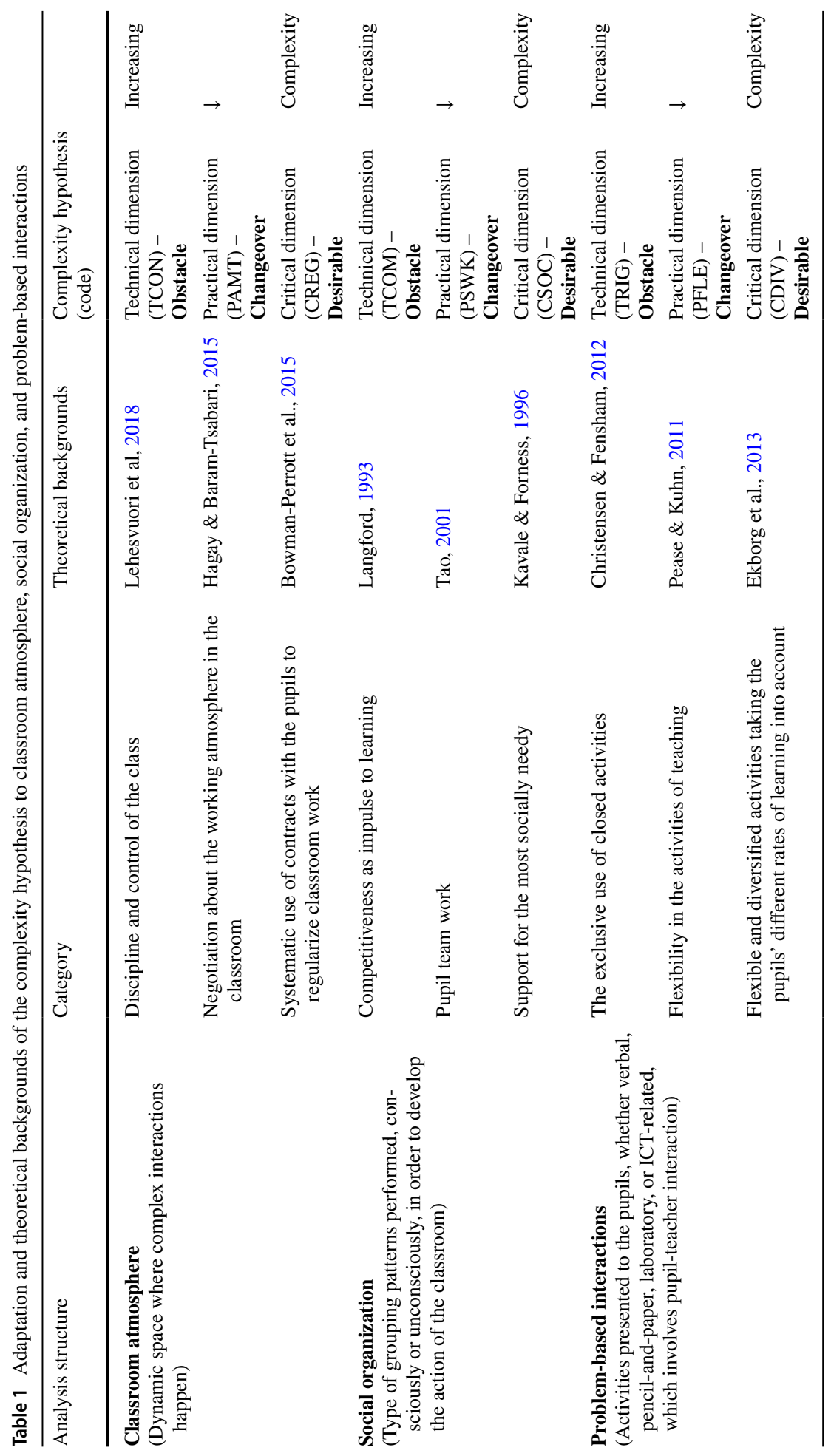




\section{Methodology and Methods}

This research is basically a longitudinal case study about a science teacher (Yin, 2018). Marina (pseudonym), the main character, is a Geology graduate. In Spain, initial science teacher education is strongly linked to a specific scientific discipline. During Marina's five years as a Geology undergraduate, she only received instruction in pedagogical and didactic content over the short period of three months. She has completed 18 years of service in the same state secondary education school in a rural town of 20000 inhabitants in SW Spain with a low socioeconomic profile, and high unemployment.

In the first years of the twenty-first century, Spain was immersed in an unprecedented change in its education system, with the introduction, among other improvements, of compulsory education until the age of 16 and constructivist, pupil-centered teaching. The training of science teachers was considered to be incomplete, due to the dissatisfaction of the teachers themselves with the new challenges introduced in the new educational legislation and the results of learning outcomes of the students. A group of teachers decided to carry out an Action-Research (A-R) project to adapt to these new requirements; in addition, the educational authorities offered professional and monetary incentives to teachers who, working in learning groups, adapted to new legislation. One of the authors, being a member of the science department of the educational center, was working on his doctoral thesis and offered his support. Because pedagogical advice was needed for teacher training, it was decided, by consensus, that this teacher would act as leader of the group (facilitator), by coaching and documenting the process of change in the aforementioned group (five science teachers).

Marina was selected for the present case study at her own request. The program followed the A-R model proposed by Kemmis and McTaggart (2000) focused on the topic "Chemistry and Solutions" (phase 1), whose knowledge was generally weak due to the type of initial teacher training she had received.

In Phase 2, the Action-Research program had ended since most of the six teachers involved had moved to other schools. However, Marina wanted to improve aspects of her teaching, and agreed that one of the authors should continue with her as an occasional advisor (about the use of information technologies in class, pupil motivation, classroom management, evaluation of learning ...), following a reflective dynamic and with similar action to that of the previous phase. On the other hand, this was in the interests of the research, since the choice of Marina laid in her desire to continue learning, but also, after all, because she was the only teacher willing to do so. The teaching topic that Marina chose for this phase of the case study was "Soil Formation" (a purely geological topic).

Finally, in Phase 3 (2011-2019), Marina was given the opportunity to read and write as narratives a major part of the reports elaborated by the researchers in the first two phases. Figure 1 shows the approximation to a timeline of part of Marina's professional development over what it is now nearly two decades and the entire research process that is the subject of this paper. For its part, Table 2 shows data collection/processing and instruments of the research.

\section{Results}

Tables 3, 4, and 5 present the overall results for the three analysis structures in the different phases for both reflection and action. The number of information units coded in each category is given in parentheses. Next, for each category, a double approach is presented, a quantitative one (frequency analysis) and a qualitative one to interpret how many 


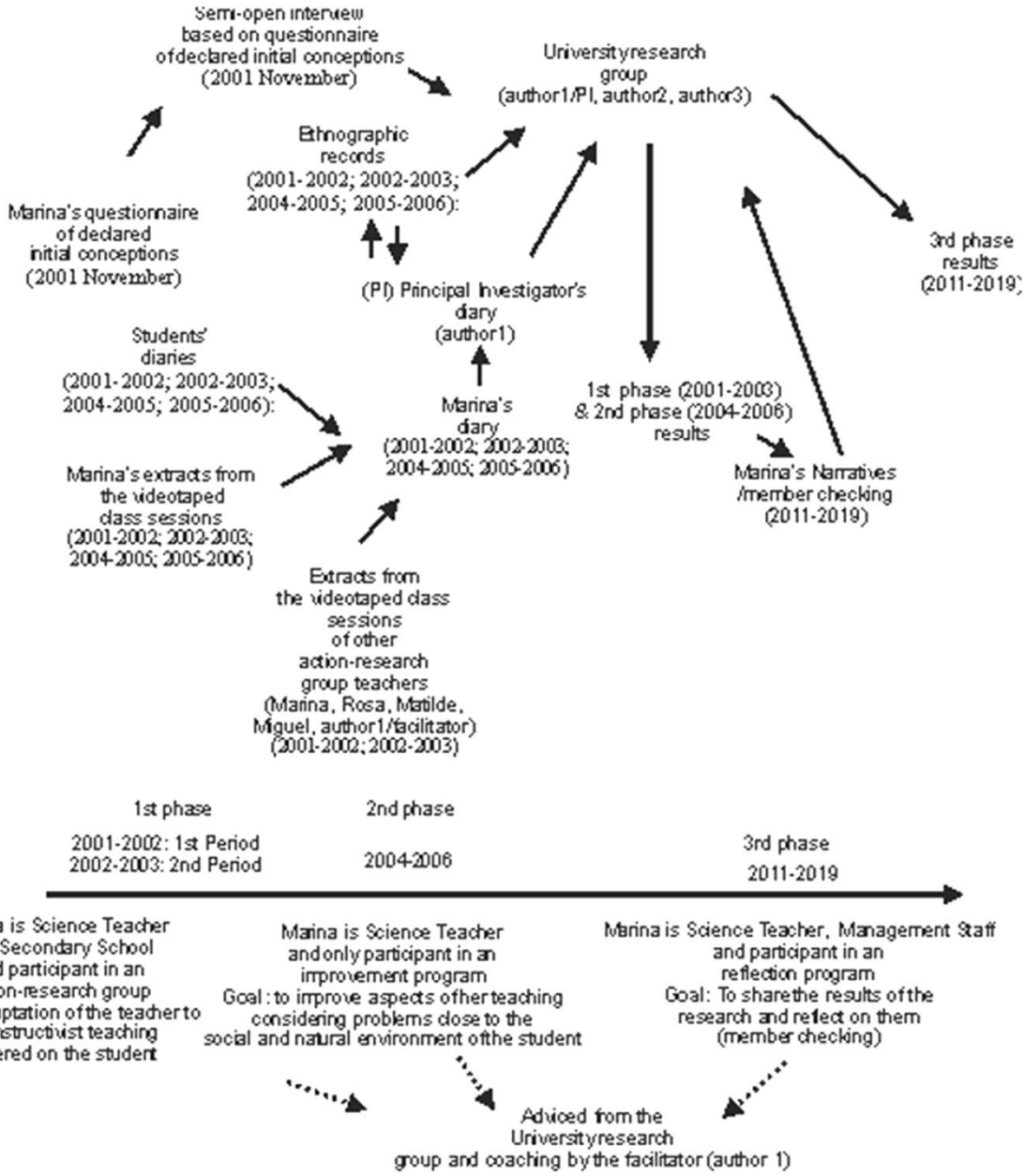

Fig. 1 Timeline of Marina's professional development, participants, and triangulation of the data.

information units belong to each dimension of the study to formulate an understanding of the representation of the reflection-action process and its development (Chi, 1997). For space reasons, only specific excerpts of Marina's reflections and actions will be presented in the following pages.

\section{Classroom Atmosphere}

\section{Analysis of Reflection}

The number of codes per session varies, decreasing in the second period of Phase 1 and increasing in Phase 2. Discipline is central to her classroom activity:

(87-96) - TCON: “...When explaining something, I had to be continually getting their attention. The class has been very relaxed for them and a little stressful for me 


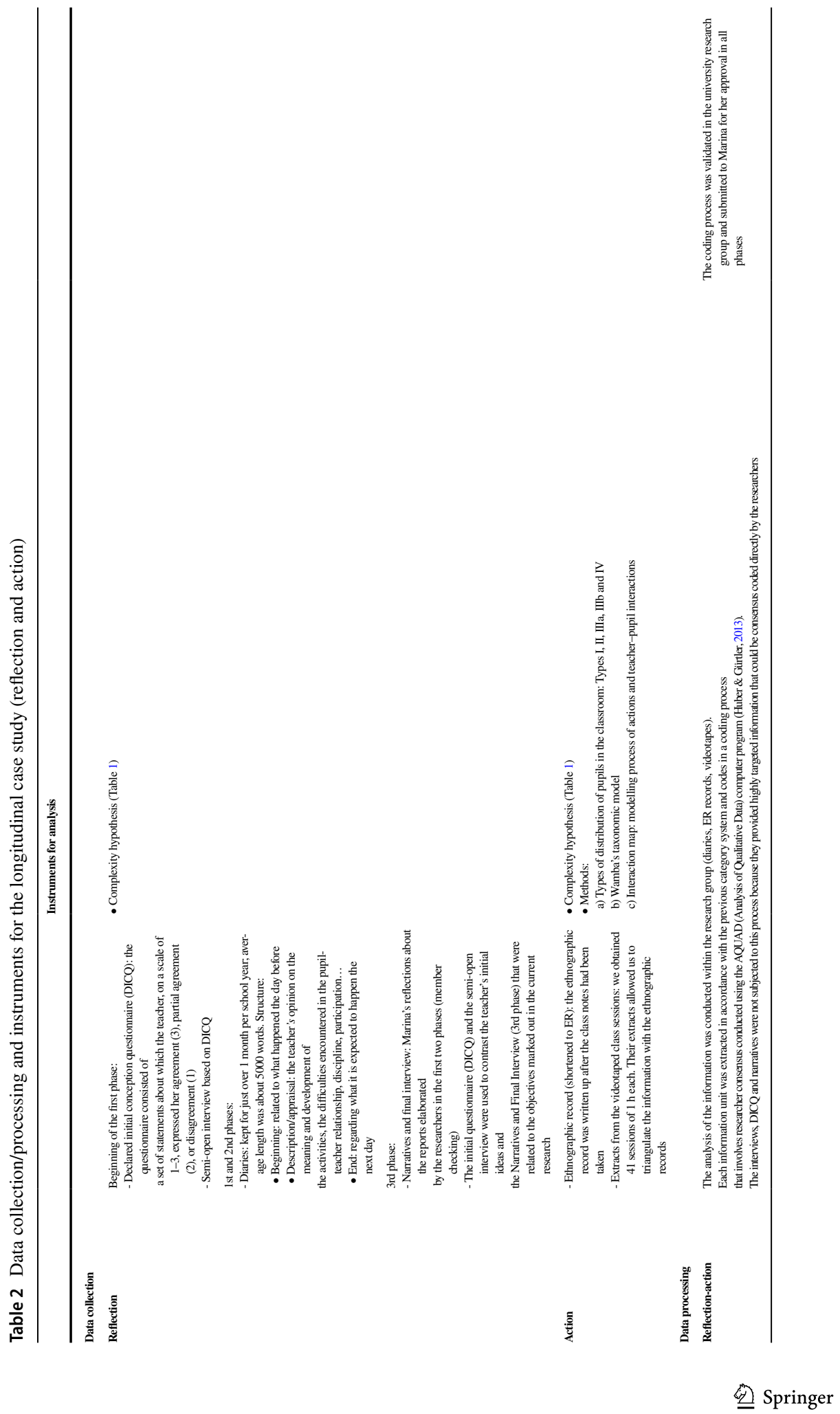




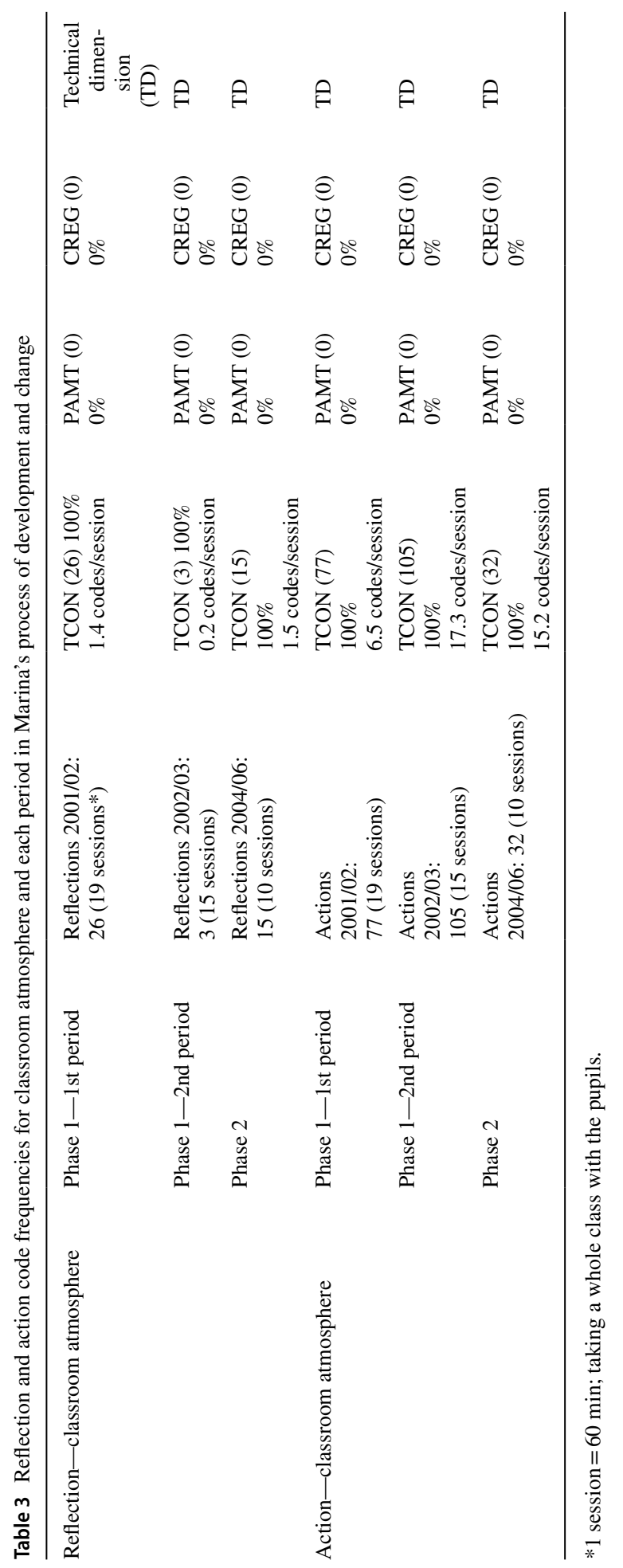




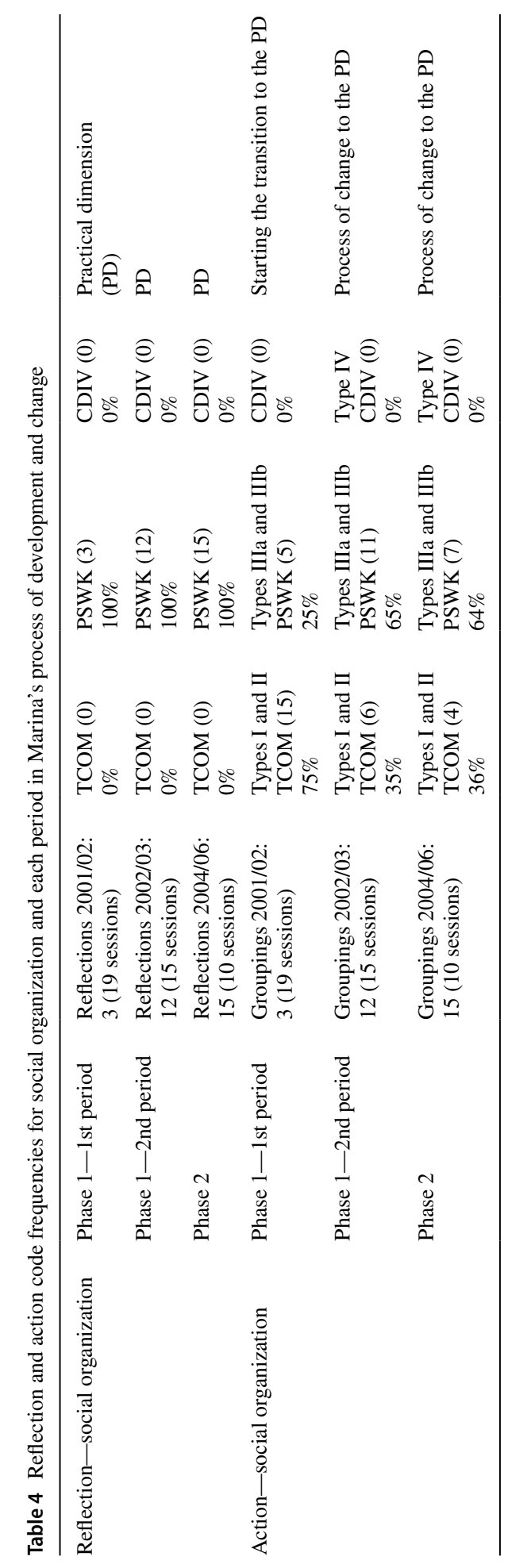




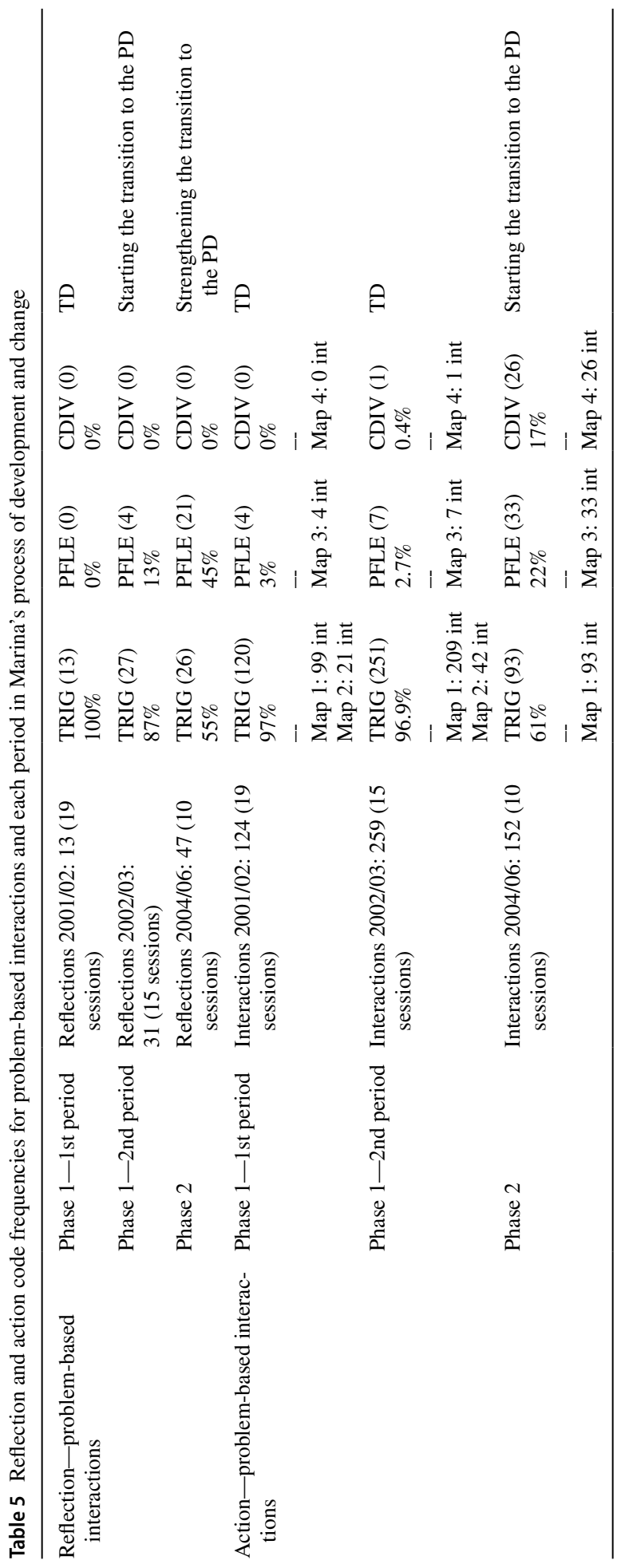


because I don't like the pupils getting out of control..." Diary 2001/2002 - Phase 1 - 1st Period.

\section{Analysis of Action}

In the second phase, she continues to reproduce the same dynamics in the classroom and the same power relations she had established previously. This relationship can be observed in the following excerpt, with specific orders on how to sit, work, and attend to the explanations:

(732-735) - TCON: "14.25 h. The teacher calls Emilio to attention, who is not listening to the explanation. The teacher tries to show him that he is not attending. She insists and says: I'm tired of you looking at the ceiling." ER3-2004/2006 - Phase 2.

\section{Key Theme-Classroom Atmosphere}

Both at the reflective level and at the level of action (Table 3), the underlying obstacle is the power relationship that Marina establishes in the classroom with her students, to the detriment of a previous negotiation agreed with them. It is a characteristic deeply rooted in her pPCK.

\section{Social Organization in the Classroom}

\section{Analysis of Reflection}

The number of codes per session varies, decreasing in the second period of Phase 1 and increasing in Phase 2. Discipline is central to her classroom activity:

(87-96) - TCON: “...When explaining something, I had to be continually getting their attention. The class has been very relaxed for them and a little stressful for me because I don't like the pupils getting out of control...” Diary 2001/2002 - Phase 1 - 1st Period.

\section{Analysis of Action}

In order to place the teacher within a certain dimension, we shall look at the type of organization of her pupils in the classroom, inquiring into the intentionality with which the groups are made. To this end, the ethnographic records allow us to distinguish the following types of groupings the teacher makes:

Type I: Pupils ordered into ranks and files ordered without any intention, only taking their interests into account (TCOM).

Type II: Pupils are grouped according to their interests, usually in groups of two (TCOM).

Types IIIa-IIIb: Formation of small groups, but without the intervention of the teacher. This allows better communication among the members of each group. It is used for laboratory activities (a) and in the classroom (b) (PSWK).

Type IV: Formation of small groups, but with the intervention of the teacher so that the groups have pupils with different abilities coexisting (CSOC). 
The results, through study of ethnographic records, show the following (Table 4). In the first course (2001/02), there was a clear preponderance of the technical dispositions, oriented towards individual work, and therefore competitiveness among the pupils. In the following courses (2002/03 and 2004/06), there was a complete turnaround in her groupings, emphasizing those that favor her pupils' cooperative work. However, there also continues to exist a lack of intentionality in the formation of the groups during this period, with the teacher leaving to the pupils the decision to form groups according to their interests and not using any type of criterion for those groups. The foregoing assessments are in line with her DICQ:

"Of course, I think debates are good in class, discussing ideas, explaining why things are the way they are..., whether they agree or disagree, and if they don't agree... why?" DICQ November 2001.

\section{Key Theme-Social Organization in the Classroom}

Marina's pPCK shows at an organizational level, her preference for student teamwork; however, this assumption is transferred to the classroom with difficulty, influenced by her need to control the student body. Support for the most socially needy remains to be developed.

\section{Problem-Based Interactions}

\section{Analysis of Reflection}

We think there has been a real development in how Marina conducts her classes and how she reflects upon them. Based on the results in Table 3, one can assess that, in this case, with a topic that she is able to handle well (Soil Formation), she can interact more with her pupils, make the classes less rigid, and, although she seems to lose some part of her control, she considers it to be of less importance as she can observe a significant improvement in the pupils' learning. Therefore, although she does not abandon her deep conviction of having a closed design for her class planning, the evidence she finds in the class and in the pupils brings her into conflict with her old theories. In other words, we think that she is strengthening her transition to the practical dimension.

\section{Analysis of Action}

For the analysis of Marina's actions, we considered the ethnographic records corresponding to the three periods of the study. For the start of a given interactive segment, we began with the notion underlying the problem and the response it induces from the pupils. For greater precision in analyzing and categorizing the problems, we followed the classification set out by Wamba (2000), since the open nature of these problems leads to pupils giving a wide variety of responses. The use of closed problems is categorized as being included in the technical dimension (closed problem). In the practical dimension, we considered three types of problem: research problem type (i) if the problem "initiates" a process of inquiry to find the answer; research problem type (c) if it is a "continuation" of such a process of inquiry; and research problem type (d) if it seeks 
to "diversify" the process. Analogously, in the critical dimension, we considered the same categorization of problems but focused on socio-environmental issues (Table 6):

We have found four activity patterns based on problems (Maps) when Marina interacts in the classroom with her students: linear rigid interaction (Map 1), cyclic rigid interaction (Map 2), flexible interaction (Map 3), diversified and flexible interaction (Map 4), as seen in Fig. 2. For example, in Phase 1-1st Period, the most common interaction used by Marina a total of 99 times was MAP 1. A variant of that intervention structure is one in which the interaction may continue with another closed problem (21 interactions), denominated MAP 2 or cyclic rigid interaction.

In Fig. 3, we present an example of a map 4 (flexible and diversified interaction). The concept of the concentration of a substance begins with an open question on how to combat the presence of microorganisms in water. This question allows for divergent thinking, as is seen in map 4. It is important to choose a question that allows for diversity in the responses, and, of course, to accept them from the pupils even if those responses are unorthodox. We would note that the Type II grouping is not the most appropriate way to promote classroom interactions.

One observes from the data in Table 5 that the pattern of Marina's actions (Maps) was different from that of her reflections. In Phase 1, Marina was situated in the technical dimension, as shown by all problem-based interactions analyzed. It appears that her participation in the Action-Research group had little influence on this aspect. However, in the second phase, in a different professional context and with a topic (Soil Formation) that was also different, the teacher's complexity began to develop towards the practical and critical dimensions. Metaphorically, the topic acts as a catalyst for Marina's development.

\section{Key Theme-Problem-Based Interactions}

In contrasting reflection and action, one observes that there has been a change in Marina's actions as part of her pPCK, and one can infer that this change owes much to the new topic (Soil Formation) and all the knowledge that this implies. Her command of this subject allows her to interact, to be flexible, and to diversify the activities. However, she shows slightly less development in her action. The idea persists that reflection precedes action. Neither can it be ignored that more than half of her activities are technical, proof of the refractory nature of the obstacles represented by her alternative teaching theories (rooted in her pPCK).

Table 6 Relation between the complexity hypothesis, Wamba's taxonomy, types of problems, and interaction maps

\begin{tabular}{llll}
\hline $\begin{array}{l}\text { Complexity hypoth- } \\
\text { esis }\end{array}$ & Wamba's taxonomy & Types of problems & Maps \\
\hline TRIG & Closed problem & Typical school problems & Map 1, Map 2 \\
PFLE & $\begin{array}{r}\text { Research problem (initial; } \\
\text { continuous; diversified) } \\
\text { Research problem (initial; } \\
\text { CDIV }\end{array}$ & Scholarship problems & Socio-environmental problems 3 \\
& \begin{tabular}{l} 
continus; diversified) \\
\hline
\end{tabular}
\end{tabular}


Fig. 2 Types of problem-based interactions
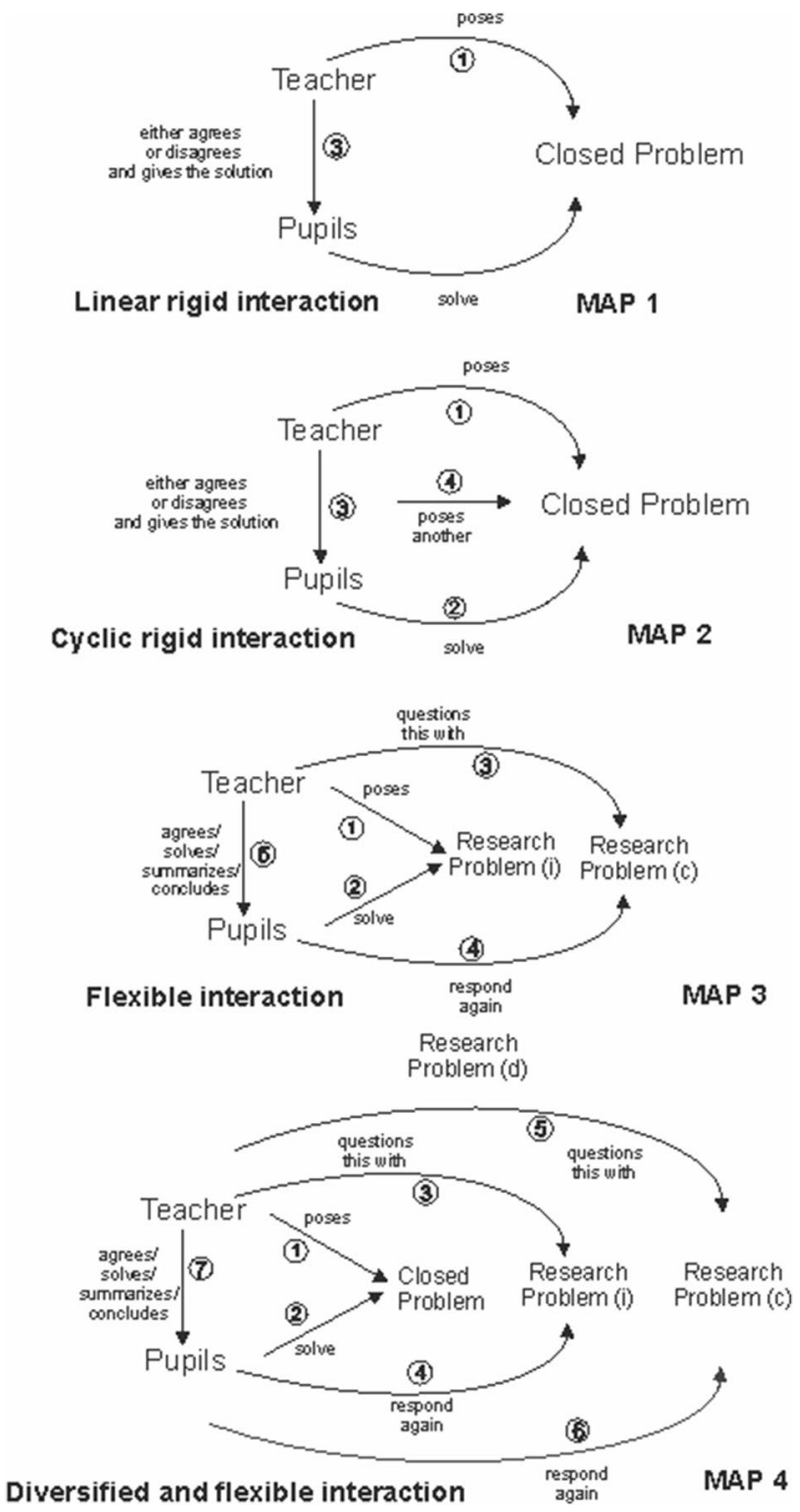

\section{Encounters of the 3rd Phase: Discussion}

Throughout this study, we have analyzed the teacher's reflection and action, capturing some specific aspects of her pPCK. The patterns that emerged in the different phases have allowed us to assess how much that unique pPCK is influenced by the shared knowledge that the cPCK entails. Using the complexity hypothesis as a methodological tool, we have tried to determine the obstacles and to know the development options that make the layers of Marina's pPCK more complex and richer towards that desirable horizon of the cPCK. 


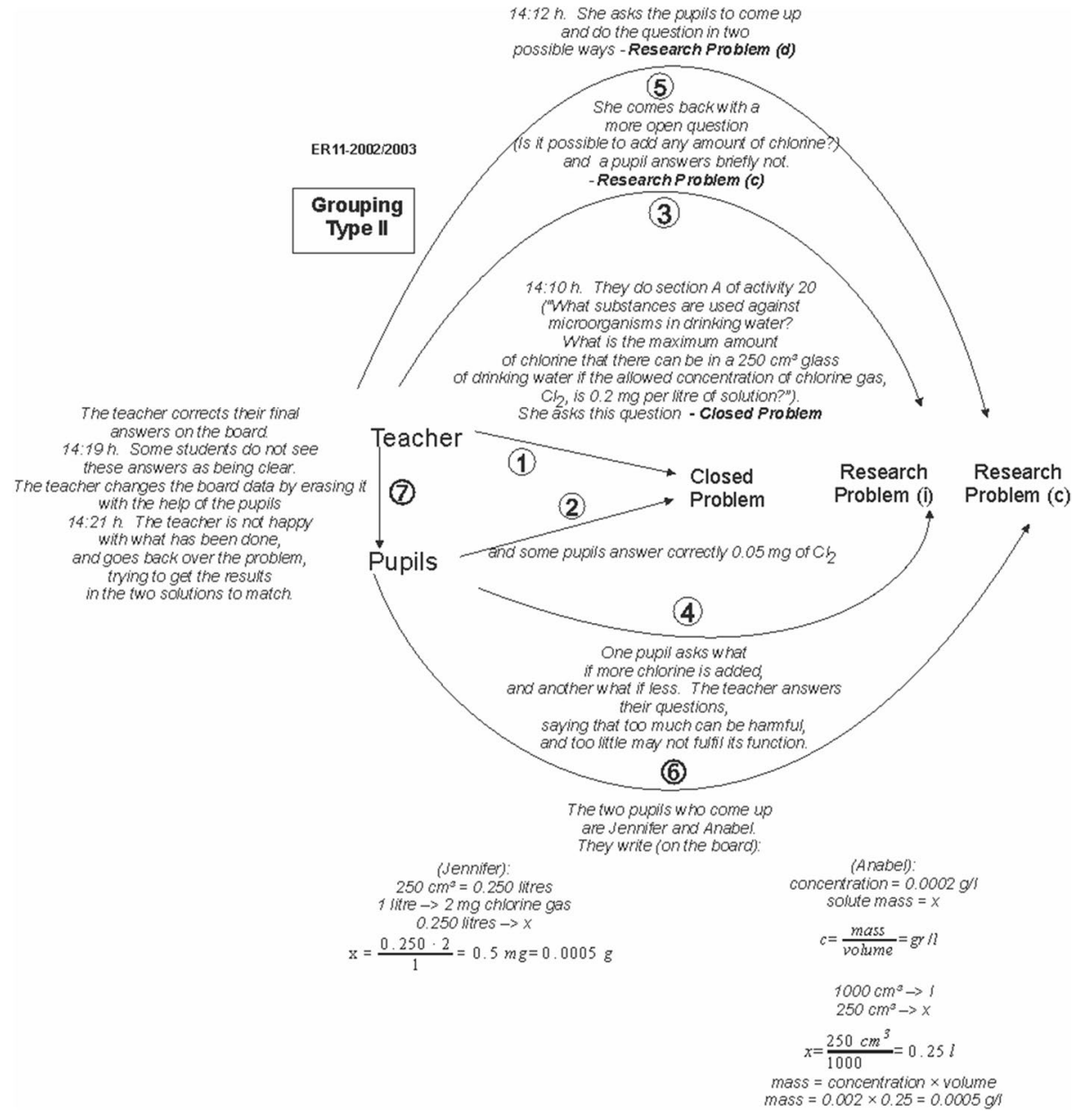

Fig. 3 Interaction map IV

\section{Research Question 1: Classroom Atmosphere}

The analysis carried out indicates that Marina professionally was in the technical dimension in classroom atmosphere, from the perspectives of both reflection and action. The impossibility of surrendering parts of her area of power and implementing some type of negotiation configures her pPCK. This was so even when the topic was one that she was knowledgeable and confident about, indicative that, from initial training of the teacher onwards, adequate preparation is an important first step in providing content knowledge and opportunities to develop proficiency in classroom management (Oliver \& Reschly, 2010). Currently, Marina is teaching adult students in non-compulsory secondary education. It was in this third phase, when we shared the analysis and results of the first and second phases, that she expressed the reflections given in Table 7, where they are contrasted with her reflections some 17 years earlier. 
This reported PCK did not necessarily reflect the pPCK of Marina currently (Mazibe et al., 2020), but it could give us clues about his teaching. In any case, it is a pervasive obstacle whose origin may be due to an incomplete Professional Knowledge (in relation to Students and Pedagogy) and to the beliefs of Marina, which suggests a stable structure of teacher cognition (Meschede et al, 2017).

\section{Research Question 2: Social Organization}

In relation to the analysis of the reflection regarding social organization, we would emphasize that Marina was within the practical dimension in all the phases of the research (see Tables 3, 4, and 5). I.e., understanding that competitiveness as an impulse for learning (TCOM) is not part of her pPCK, and, at least from what her reflections reveal, she believes in pupil teamwork (PSWK).

However, analysis of her actions in the classroom yields different results. During the second phase, in spite of the change in content and all that this implies for her actions in the classroom, the form of social organization persists within this transitional stage, without reaching any change towards support for those with most social needs. We would say that the reflection-action tandem is refractory against progress towards critical social consciousness. This obstacle is closer to Marina's beliefs than to her knowledge, which as verified by Mavhunga and Rollnick (2016); these beliefs do not seem to necessarily follow the development path of the topic-specific PCK (TSPCK).

\section{Research Question 3: Problem-Based Interactions}

Regarding the problem-based interactions, the analysis showed evident development in the teacher's reflection and action over the years the study lasted. Her reflections in the first period of Phase 1 showed her thinking to be centered on interactions with rigid structures, with no room left for discussion. Her actions had the same orientation. During the second period of that phase, despite working on the same curricular content (Solutions in Chemistry), something began to change as was noticeable in her apparent tiredness with repeating these same routines. In this period, her reflectiveness related to that content began to include the possibility of contextualizing problems and giving her pupils more time to respond. Such reflection about her own practice and its outcomes should stimulate Marina's processes of learning and change (Simon \& Campbell, 2012).

Are there reasons for this change? We could point to the content, or maybe it was about the connections she was able to make between the topic and her pupils, or that she was more comfortable with the representations she used, or even that the academic language was more accessible to the pupils. At this point, the importance of the A-R group cannot be

Table 7 Initial-to-final contrast of Marina's thoughts about classroom atmosphere

\begin{tabular}{lc}
\hline Interview November 2001 & Final (2019)—-third phase \\
\hline I don't like pupils getting out of control in class & $\begin{array}{l}\text { Experience teaches you to have more control } \\
\text { [it] makes me very nervous, I don't even let them }\end{array}$ \\
$\begin{array}{ll}\text { over things and people, even over yourself, so } \\
\text { thathe... }\end{array}$ & $\begin{array}{l}\text { would } \boldsymbol{b} \boldsymbol{e} \text { more flexible, even leading to negotia- } \\
\text { tion with them }\end{array}$ \\
\hline
\end{tabular}


overestimated (Luehmann, 2008), since it shares aspirations with the professional learning community (PLC) as a means of generating pedagogical learning and change among the participating teachers with the horizon of the search for social justice (Feldman \& Fataar, 2016), and interesting tool for negotiation in times of curricular changes (Friedrichsen \& Barnett, 2018).

\section{General Research Question}

She had more security in her teaching due to stronger professional knowledge, and her reflective Action-Research work acted synergically to help re-orient her ideas (Henze et al., 2008). While the evidence showed her reflection to have had the greater influence on the development of her ideas, our interpretation is that the reflective practice of those early years served to trigger her subsequent professional development. In her own words:

"Between being part of the working group and working alone, I would tend to prefer my group work as it allowed me to share my experiences and my fears when they arose ... I listened to the others' experiences and feelings, and this helped me to learn things about how to give my classes...." (Marina: 2012 - third phase).

However, some aspects of her development remain incomplete. An example is her ability to handle groups of pupils with different skill levels and learning rates by giving special support for those with the most social needs. Also, even with a greater mastery of her knowledge forged through her professional practice, her ability to set flexible and diversified activities and a critical social organization, according to the complexity hypothesis, is still inconclusive, as she herself acknowledges. We believe this is attributable to inefficient professional knowledge bases due to inadequate initial training. It is an underlying theme that recurs over the years (Table 8):

In essence, one question remains: Why is this development incomplete? We would point to Marina's highly transmissive image of teaching, very deeply rooted in her beliefs, as well as the passive role she gives her pupils who have very little chance to construct their own learning (transmissive-receptive pattern). These beliefs act as powerful filters and amplifiers in her classroom practice (Gess-Newsome, 2015).

Throughout the study, we witnessed the importance of constructing a solvent, competent, and adaptive professional knowledge that integrates reflection-practice. This involves breaking with those routines and obstacles that, in the case of both social organization and problem-based interactions, make it hard for pupils to construct their own meaningful knowledge. In particular, the repetition of predictable teacher-pupil interaction algorithms and structures constitutes the most important obstacle, without neglecting a more socio-critical vision towards the pupils with the greatest difficulties (physical, psychical, and social).

Table 8 Marina's thoughts in Phase 3 about attention to diversity

\begin{tabular}{lc}
\hline Third phase (2012) & Third phase (2019) \\
\hline $\begin{array}{l}\text { As for attention to diversity in the classroom, I think } \\
\text { this is a utopia whenever you have } 20 \text { to } 30 \text { pupils }\end{array}$ & $\begin{array}{c}\text { And with regard to the attention to diversity is } \\
\text { something that I still don't know how to do... }\end{array}$ \\
$\begin{array}{l}\text { in a class; to me, it is humanly impossible to imple- } \\
\text { ment real diversity with } 25 \text { pupils }\end{array}$ & \\
\hline
\end{tabular}


A teacher's professional knowledge needs to be constructed starting from the earliest stages of initial teacher education (Beyer \& Davis, 2011) and continuing throughout the teacher's professional development. This can be a daunting task since there is specific knowledge for each area of the content that has to be taught and, besides, the components of PCK interact among each other. In our study, the topics taught (Solutions versus Soil) come from different disciplines (Chemistry and Geology), which means that the knowledge and strategies used are different in nature even though they share some facets in common. Plausibly, Marina has a better command of the topic-specific PCK (TSPCK) components (learners' prior knowledge, curricular saliency, topic's understanding, representations, teaching strategies: Mavhunga, 2020; Mavhunga \& Rollnick, 2013) and that allows her to diversify her problem-based interactions in relation to the soil topic.

Action-research or PLC constitutes powerful tools with which teachers can develop and maintain up-to-date practical theories by sharing their knowledge and experience with their peers. In any case, self-reflection and reflecting is a fruitful approach to improve (Bradbury et al., 2018).

This does not exclude the clear benefits of an initial pedagogical training that enriches the teacher professional knowledge with which they then can construct a personal knowledge that is adaptable to the reality of classroom practice. Therefore, this content-related knowledge must be built from the earliest stages of a teacher's initial training and their first teaching experiences (Coetzee et al., 2020; Kaya et al., 2021). In this sense, Mavhunga (2019) indicates that working TSPCK in teacher training can improve pPCK, insofar as it is articulated as a grain size in the continuum of PCK found within the three realms of PCK (collective, personal, and enacted).

\section{Conclusions and Limitations}

Carlson and Daehler (2019) defend, in the RCM of PCK, the existence of a continuum between the private space (pPCK) and the public space (cPCK) where the learning context plays an amplifier and a filter between both realms. However, in our work, it is clear, or so we believe, that this development is not guaranteed and is not without obstacles. In Marina's case, the fundamental obstacle lies in her Beliefs about power that prevent her from implementing some type of negotiation (classroom atmosphere). On the other hand, although they are not real obstacles, she must assume the need to support those with most social needs in her teaching (social organization), and to diversify the teaching-learning episodes in the classroom (problem-based interactions). In addition, TSPK and learning in the A-R group act synergistically to support her development (Bravo \& Cofré, 2016).

The state of development in which Marina is at present, in accordance with Fuller (1969), corresponds to the concern about one's ability to understand the pupils' capacities, to specify objectives for them, to assess their improvement, to point out one's own contribution to the pupils' difficulties and improvement, and to evaluate oneself in terms of their advances. However, there are many challenges that must be overcome. We have shown the limitations of learning from experience (as opposed to long-term, sustained, and goal-oriented professional development), and this is a task that cannot be developed in isolation, since building a professional learning continuum depends on the partnerships of schools, unions, and universities. Each has a critical role to play, and none of them can do it alone (Feiman-Nemser, 2001). Therefore, the main implication is that Marina must strengthen her specific professional knowledge of the different subjects she teaches and 
integrate herself into these learning networks or PLC (Chan \& Yung, 2018), although even more important is the fact of facing new challenges in the classroom, interacting with her pupils, which will inevitably lead to her giving up parts of her power.

The new conceptualization of the PCK has allowed us to focus this research on a shared theoretical framework which we humbly wish to contribute to, because, as has recently been noted (Chan \& Hume, 2019), in the field of science education there lack both longitudinal studies of PCK development and valid measurement instruments of PCK in authentic classroom contexts and situations, because as Alonzo et al. (2019) have pointed, at the time of instruction, what happens is tacit.

The main limitation was knowing how Marina currently develops her classroom action. A rival theory of our case is that, in reality, neither her belonging to an A-R group nor the chosen teaching topic had any impact on Marina's reflection-action; simply, the daily routine over the years has marked the evolution of her classroom practice. However, the data and Marina's own words seem to contradict this alternative hypothesis (Yin, 2018). The emerging patterns found seem to confirm our hypothesis, although it remains to be determined what is due to the topic and what is due to the A-R group (possibly very difficult to resolve); provisionally, we can accept that both acted synergistically, catalyzing change and development.

Recently, the Committee on the Rights of Persons with Disabilities of The United Nations has expressed concern because "... in the Spanish education system there is no widespread recognition of the human rights model of disability... Inclusion is understood by a large majority of teachers as a principle, trend or pedagogical method rather than as a right (UN, 2018: p. 14)." In view of this appalling statement, is it not plausible to find a certain parallelism with Marina's development and the obstacles she is confronted with? This situation may be aggravated still further by the current pandemic as UNICEF (2020) has pointed out.

Acknowledgements We are grateful to Marina; without her, nothing was/is/will be possible.

Author Contribution The three authors have participated in the study.

Funding Open Access funding provided thanks to the CRUE-CSIC agreement with Springer Nature. This project has funding for its translation and open access charge from University of Huelva/CBUA, Spain.

Data Availability Data and materials are at the disposal of the editors.

Code Availability The Spanish encoding files in AQUAD are available.

\section{Declarations}

Ethics Approval The studio has implemented all necessary ethical approvals.

Consent to Participate The authors consent to participate.

Consent for Publication The authors consent to the publication.

Competing Interests The authors declare no competing interests.

Open Access This article is licensed under a Creative Commons Attribution 4.0 International License, which permits use, sharing, adaptation, distribution and reproduction in any medium or format, as long as you give appropriate credit to the original author(s) and the source, provide a link to the Creative Commons licence, and indicate if changes were made. The images or other third party material in this article are included in the article's Creative Commons licence, unless indicated otherwise in a credit line to the 
material. If material is not included in the article's Creative Commons licence and your intended use is not permitted by statutory regulation or exceeds the permitted use, you will need to obtain permission directly from the copyright holder. To view a copy of this licence, visit http://creativecommons.org/licenses/by/4.0/.

\section{References}

Alonzo, A. C., Berry, A. \& Nilsson, P. (2019). Unpacking the complexity of science teachers' PCK in action: Enacted and personal PCK. In A. Hume, R. Cooper and A. Borowski (eds.) Repositioning Pedagogical Content Knowledge in Teachers' Knowledge for Teaching Science (271-286). Singapore: Springer Nature.

Anderson, J. (2019). In search of reflection-in-action: An exploratory study of the interactive reflection of four experienced teachers. Teaching and Teacher Education, 86, 102879. https://doi.org/10.1016/j.tate. 2019.102879

Astolfi, J. P., \& Peterfaivi, B. (1999). Obstacles et construction de situations didactiques en sciences expérimentales. Aster, 16, 103-141. https://doi.org/10.4267/2042/8578

Bachelard, G. (1983). La Formation de l'esprit Scientifique. Paris, France: J. Vrin.

Barendsen, E., \& Henze, I. (2019). Relating teacher PCK and teacher practice using classroom observation. Research in Science Education, 49, 1141-1175. https://doi.org/10.1007/s11165-017-9637-z

Beyer, C. J., \& Davis, E. A. (2011). Learning to critique and adapt science curriculum materials: Examining the development of pre-service elementary teachers' pedagogical content knowledge. Science Education, 96(1), 130-157. https://doi.org/10.1002/sce.20466

Bowman-Perrott, L., Burke, M. D., de Marin, S., Zhang, N., \& Davis, H. (2015). A meta-analysis of singlecase research on behavior contracts: Effects on behavioral and academic outcomes among children and youth. Behavior Modification, 39(2), 247-269. https://doi.org/10.1177/2F0145445514551383

Bradbury, L. U., Wilson, R. E., \& Brookshire, L. E. (2018). Developing elementary science PCK for teacher education: Lessons learned from a second grade partnership. Research in Science Education, 48, 1387-1408. https://doi.org/10.1007/s11165-016-9607-x

Bravo, P., \& Cofré, H. (2016). Developing biology teachers' pedagogical content knowledge through learning study: The case of teaching human evolution. International Journal of Science Education, 38(16), 2500-2527. https://doi.org/10.1080/09500693.2016.1249983

Carlson, J. \& Daehler, K. R. (2019). The refined consensus model of pedagogical content knowledge in science education. In A. Hume, R. Cooper and A. Borowski (eds.) Repositioning Pedagogical Content Knowledge in Teachers' Knowledge for Teaching Science (77-92). Singapore: Springer Nature.

Chan, K. K. H \& Hume, A. (2019). Towards a consensus model: Literature review of how science teachers' pedagogical content knowledge is investigated in empirical studies. In A. Hume, R. Cooper and A. Borowski (eds.) Repositioning Pedagogical Content Knowledge in Teachers' Knowledge for Teaching Science (3-76). Singapore: Springer Nature.

Chan, K. K. H., \& Yung, B. H. W. (2018). Developing pedagogical content knowledge for teaching a new topic: More than teaching experience and subject matter knowledge. Research in Science Education, 48, 233-265. https://doi.org/10.1007/s11165-016-9567-1

Chi, M. T. H. (1997). Quantifying qualitative analyses of verbal data: A practical guide. Journal of the Learning Sciences, 6, 271-315.

Coetzee, C., Rollnick, M. \& Gaigher, E. (2020). Teaching electromagnetism for the first time: A case study of pre-service science teachers' enacted pedagogical content knowledge. Res Sci Educ., 1-22.https:// doi.org/10.1007/s11165-020-09948-4

Christensen, C., \& Fensham, P. J. (2012). Risk, uncertainty and complexity in science education. In B. J. Fraser, K. Tobin, \& C. J. McRobbie (Eds.), Second International Handbook of Science Education (pp. 751-769). Springer Publishing.

Depaepe, F., Verschaffel, L., \& Kelchtermans, G. (2013). Pedagogical content knowledge: A systematic review of the way in which the concept has pervaded mathematics educational research. Teaching and Teacher Education, 34, 12-25. https://doi.org/10.1016/j.tate.2013.03.001

Ekborg, M., Ottander, C., Silfver, E., \& Simon, S. (2013). Teachers' experience of working with socio-scientific issues: A large scale and in depth study. Research in Science Education, 43(2), 599-617. https:// doi.org/10.1007/s11165-011-9279-5

Feiman-Nemser, S. (2001). From preparation to practice: Designing a continuum to strengthen and sustain teaching. Teachers College Record, 103(6), 1013-1055. 
Feldman, J., \& Fataar, A. (2016). Dialogical habitus engagement: The twists and turns of teachers' pedagogical learning within a professional learning community. Perspectives in Education, 34(3), 98-105. https://doi.org/10.18820/2519593X/pie.v34i3.8

Friedrichsen, P. J., \& Barnett, E. (2018). Negotiating the meaning of Next Generation Science Standards in a secondary biology teacher professional learning community. Journal of Research in Science Teaching, 55(7), 999-1025. https://doi.org/10.1002/tea.21472

Fuller, F. F. (1969). Concerns of teachers: A developmental conceptualization. American Educational Research Journal, 6(2), 207-226.

Gess-Newsome, J. (2015). A model of teacher professional knowledge and skill including PCK: Results of the thinking from the PCK Summit. In A. Berry, P. Friedrichsen, \& J. Loughran (Eds.), Re-examining Pedagogical Content Knowledge in Science Education (pp. 28-42). Routledge.

Habermas, J. (1987). Knowledge and Human Interests. Polity Press.

Hagay, G., \& Baram-Tsabari, A. (2015). A strategy for incorporating students' interests into the high-school science classroom. Journal of Research in Science Teaching, 52(7), 949-978. https://doi.org/10.1002/ tea. 21228

Henze, I., Van Driel, J. H., \& Verloop, N. (2008). Development of experienced science teachers' pedagogical content knowledge of models of the solar system and the universe. International Journal of Science Education, 30(10), 1321-1342. https://doi.org/10.1080/09500690802187017

Huber, G. L. \& Gürtler, L. (2013). AQUAD 7. Manual del programa para analizar datos cualitativos. Tübingen (DE): Softwarevertrieb Günter Huber.

Kam Ho, K. \& Hume, A. (2019). Towards a consensus model: Literature review of how science teachers' pedagogical content knowledge is investigated in empirical studies. In A. Hume, R. Cooper and A. Borowski (eds.) Repositioning Pedagogical Content Knowledge in Teachers' Knowledge for Teaching Science (3-76). Singapore: Springer Nature. https://doi.org/10.1007/978-981-13-5898-2_2

Kavale, K. A., \& Forness, S. R. (1996). Social skill deficits and learning disabilities: A meta-analysis. Journal of learning disabilities, 29(3), 226-237. 10.1177\%2F002221949602900301

Kaya, Z., Kaya, O. N., Aydemir, S., \& Ebenezer, J. (2021). Knowledge of student learning difficulties as a plausible conceptual change pathway between content knowledge and pedagogical content knowledge.Research in Science Education, 1-33.https://doi.org/10.1007/s11165-020-09971-5

Kemmis, S., \& McTaggart, R. (2000). Participatory action research. In N. Denzin \& Y. Lincoln (Eds.), Handbook of Qualitative Research (2nd ed., pp. 567-605). Sage.

Langford, G. (1993). La enseñanza y la idea de práctica social. En W. Carr (Ed.) Calidad de la enseñanza e Investigación-Acción (Teaching quality and Action Research) (pp. 25-39). Sevilla: Díada.

Lehesvuori, S., Ramnarain, U., \& Viiri, J. (2018). Challenging transmission modes of teaching in science classrooms: Enhancing learner-centredness through dialogicity. Research in Science Education, 48(5), 1049-1069. https://doi.org/10.1007/s11165-016-9598-7

Luehmann, A. L. (2008). Identity development as a lens to science teacher preparation. Science Education, 91(5), 822-939.

Magnusson, S., Krajcik, J. S. \& Borko, H. (1999). Nature, sources and development of pedagogical content knowledge for science teaching. In: J. Gess-Newsome \& N. Lederman (eds.). Examining Pedagogical Content Knowledge: The Construct and its Implications for Science Education (pp. 95-132). Kluwer A. P.

Mavhunga, E. (2019). Exposing pathways for developing teacher pedagogical content knowledge at the topic level in science. In A. Hume, R. Cooper and A. Borowski (eds.) Repositioning Pedagogical Content Knowledge in Teachers' Knowledge for Teaching Science (129-148). Singapore: Springer Nature. https://doi.org/10.1007/978-981-13-5898-2_5

Mazibe, E. N., Coetzee, C., \& Gaigher, E. (2020). A comparison between reported and enacted pedagogical content knowledge (PCK) about graphs of motion. Research in Science Education, 50(3), 941-964. https://doi.org/10.1007/s11165-018-9718-7

Mavhunga, E. (2020). Revealing the structural complexity of component interactions of topic-specific PCK when planning to teach. Res Sci Educ., 50, 965-986 (2020). https://doi.org/10.1007/ s11165-018-9719-6

Mavhunga, E., \& Rollnick, M. (2013). Improving PCK of chemical equilibrium in pre-service teachers. African Journal of Research in Mathematics, Science and Technology Education, 17(1-2), 113-125. https://doi.org/10.1080/10288457.2013.828406

Mavhunga, E., \& Rollnick, M. (2016). Teacher-or learner-centred? Science teacher beliefs related to topic specific pedagogical content knowledge: A South African case study. Research in Science Education, 46(6), 831-855. https://doi.org/10.1007/s11165-015-9483-9 
Meschede, N., Fiebranz, A., Möller, K., \& Steffensky, M. (2017). Teachers' professional vision, pedagogical content knowledge and beliefs: On its relation and differences between pre-service and in-service teachers. Teaching and Teacher Education, 66, 158-170. https://doi.org/10.1016/j.tate.2017.04.010

Morin, E. (1999). Seven Complex Lessons in Education for the Future. Unesco Publishing.

Murray, J. (2014). Teacher educators' constructions of professionalism: A case study. Asia-Pacific Journal of Teacher Education, 48(1), 7-21. https://doi.org/10.1080/1359866X.2013.870971

Oliver, R. M., \& Reschly, D. J. (2010). Teacher preparation in classroom management: Implications for students with emotional and behavioral disorders. Behavioral Disorders, 35, 188-199.

Park, S., \& Oliver, J. S. (2008). Revisiting the conceptualisation of pedagogical content knowledge (PCK): PCK as a conceptual tool to understand teachers as professionals. Research in Science Education, 38(3), 261-284. https://doi.org/10.1007/s11165-007-9049-6

Pease, M. A., \& Kuhn, D. (2011). Experimental analysis of the effective components of problem-based learning. Science Education, 95(1), 57-86. https://doi.org/10.1002/sce.20412

Shulman, L. (1986). Those who understand: Knowledge growth in teaching. Educational Researcher, 15(2), 4-14.

Simon, S., \& Campbell, S., et al. (2012). Teacher learning and professional development in science education. In B. J. Fraser (Ed.), Second International Handbook of Science Education (pp. 307-321). Springer Publishing.

Taggart, G. L., \& Wilson, A. P. (2005). Promoting reflective thinking in teachers: 50 action strategies ( $2 \mathrm{nd}$ ed.). Corwin Press.

Tao, P. K. (2001). Developing understanding through confronting varying views: The case of solving qualitative physics problems. International Journal of Science Education, 23(12), 1211-1218. https://doi. org/10.1080/09500690110038602

UN [United Nations] (2018). Inquiry concerning Spain carried out by the Committee under article 6 of the Optional Protocol to the Convention. Retrieved June 8, 2019, from: https://digitallibrary.un.org/record/ 1483922

UNICEF (2020). Protecting the most vulnerable children from the impact of coronavirus: An agenda for action. Retrieved September 25, 2020, from: https://www.unicef.org/coronavirus/agenda-for-action

Vázquez-Bernal, B., Jiménez-Pérez, R., \& Mellado, V. (2007). El desarrollo profesional del profesorado de ciencias como integración reflexión y práctica. La Hipótesis de la Complejidad. Revista Eureka sobre Enseñanza y Divulgación de las Ciencias, 4(3), 372-393. https://doi.org/10.25267/Rev_Eureka_ ensen_divulg_cienc.2007.v4.i3.01

Vázquez-Bernal, B., Mellado, V., Jiménez-Pérez, R., \& Taboada, M. C. (2012). The process of change in a science teacher's professional development: A case study based on the types of problems in the classroom. Science Education, 96(2), 337-363. https://doi.org/10.1002/sce.20474

Wamba, A. M. (2000). Didactic models and obstacles to professional development: Case studies with teachers of Experimental Sciences in Secondary Education: doctoral dissertation. Retrieved April 14, 2015, from http://rabida.uhu.es/dspace/handle/10272/2717

Yin, R. K. (2018). Case Study: Research and Applications (6th ed.). Sage Publication Inc.

Publisher's Note Springer Nature remains neutral with regard to jurisdictional claims in published maps and institutional affiliations. 